\title{
HispanismeS
}

Revue de la Société des Hispanistes Français

\section{Clarice e o perigo de viver}

clarice ou le danger de vivre

Clarice o el peligro de vivir

Clarice or the Danger of Living

\section{Yudith Rosenbaum}

\section{OpenEdition}

\section{Journals}

\section{Edição electrónica}

URL: https://journals.openedition.org/hispanismes/536

DOI: 10.4000/hispanismes.536

ISSN: 2270-0765

\section{Editora}

Société des Hispanistes Français

\section{Refêrencia eletrónica}

Yudith Rosenbaum, «Clarice e o perigo de viver », HispanismeS [En ligne], 15 | 2020, mis en ligne le 01 juin 2020, consulté le 31 juillet 2021. URL : http://journals.openedition.org/hispanismes/536 ; DOI https://doi.org/10.4000/hispanismes.536

Este documento foi criado de forma automática no dia 31 julho 2021.

\section{(c) (i) $\odot$}

Les contenus de cette revue sont mis à disposition selon les termes de la Licence Creative Commons Attribution - Pas d'Utilisation Commerciale - Pas de Modification 4.0 International. 


\section{Clarice e o perigo de viver}

Clarice ou le danger de vivre

Clarice o el peligro de vivir

Clarice or the Danger of Living

Yudith Rosenbaum

É numa casa que a gente se sente só. Não do lado de fora, mas dentro.

Marguerite Duras

Um pouco cansada, com as compras deformando o novo saco de tricô, Ana subiu no bonde.

Depositou o volume no colo e o bonde começou a andar. Recostou-se, então, no banco procurando conforto num suspiro de meia satisfação.

Clarice Lispector

\section{Introdução}

1 Assim começa o conto "Amor" de Clarice Lispector, escritora judia nascida na Ucrânia, que migrou para o Brasil com a família, aportando em Maceió, com um ano e dois meses de idade, em 1922. O texto integra o volume Laços de família (1960) ${ }^{1}$, o primeiro e um dos mais importantes livros de contos da autora - talvez da literatura brasileira do século XX. Através dele é possível conhecer as inscrições, não só de uma experiência biográfica intensa transfigurada pela ficção, mas, sobretudo, de um estilo até hoje desconcertante. Pretendo partir, inicialmente, de algumas referências da trajetória familiar de Lispector e desentranhar, seguindo as pistas textuais, certas questões cruciais de sua obra, desdobradas e retomadas nos livros seguintes. 0 estudo da categoria do estranhamento em suas articulações com a noção de "estrangeiro"- encontra neste conto uma configuração privilegiada, uma vez que o texto põe em cena mobilizadores e efeitos da desfamiliarização, núcleo do ato de estranhar. 
2 A família de Lispector, pai, mãe e três filhas, faz parte do fluxo migratório de judeus, nas duas primeiras décadas do século XX, fugindo dos pogroms que ainda ocorriam após a guerra civil russa. Outras viagens, dentro e fora do Brasil, marcariam a autora que, ainda criança, saiu de Maceió para Recife e depois, já adolescente, mudou-se para o Rio de Janeiro². Com o marido embaixador, Clarice viveu em diversos países (Itália, Suíça, Inglaterra, EUA, entre outros), o que deixou marcas importantes dessa vivência nômade em sua escrita, cadinho onde deságuam as experiências mais precoces enlaçadas às de sua vida adulta. Longe de ser um estudo de cunho biografizante, trata-se aqui de compreender a difícil trama entre e o fundo insondável do que foi vivido e a sua transmutação pela ficção. O foco da análise estará na escritura resultante dos complexos fios que enlaçam vida e obra.

3 Para acompanhar esses traços e reconhecê-los como atrelados aos processos ficcionais e singulares da autora, tomo como inspiração duas observações de críticos que me acompanham ao longo deste estudo. A primeira é de Berta Waldman, que situou com agudeza o lugar da diáspora judaica na obra de Clarice:

Fazendo eco com esses deslocamentos no espaço, as personagens de Clarice Lispector entregam-se também elas a uma mobilidade inesgotável manifestada em sucessivas viagens que marcam o destino de várias delas, sempre de partida ${ }^{3}$.

4 Ainda que a abordagem do conto aqui proposta não dê centralidade às determinações específicas da história judaica, é inegável que seus ecos se fazem sentir ao longo da obra toda de Clarice. A procura de um lugar próprio às personagens e à autora, em sua deriva de estrangeiras em relação aos outros e a si mesmas, revela-se, por exemplo, nesta frase de uma carta de Clarice à irmã: "[...] pensando bem, não há um verdadeiro lugar para se viver. Tudo é terra dos outros, onde os outros estão contentes"4. A mesma peregrinação em meio à "terra dos outros" se verifica em sua escrita, já que a autora deslocava e intercambiava textos, fazendo reaparecer trechos de contos, contos inteiros ou partes de romances como crônicas e vice-versa, alterando sentidos e gêneros literários de seus escritos ao republicá-los. Como mostra Waldman, "fragmentos de textos, em diálogo interno, endogâmico, migram incessantemente, criando, a cada nova

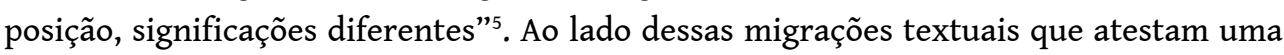
errância própria da linguagem e de quem nela se (des)encontra, percebem-se outros tipos de trânsitos, convocados aqui para pensar, na palavra literária, as confluências de traços da história pessoal e uma dimensão sociopolítica inextricável de sua face subjetiva ${ }^{6}$. Trabalho aqui com a ideia de que a noção de estrangeiridade (externa e interna ao sujeito) opera nas entranhas do texto clariceano, estabelecendo vizinhanças profundas com "Das Unheimliche", o estranho familiar conceituado por Freud.

5 A segunda observação vem de José Miguel Wisnik, que destaca uma trilogia, não assumida explicitamente pela autora, formada pelos três livros da década de 60, Laços de familia, A legião estrangeira e A paixão segundo G.H. O autor assim caracteriza o período de realização das obras:

Matrimônio e desquite, pertinência dos laços familiares e abandono à estranheza do mundo e, mais que isso, arraigamento profundo e desarraigamento radical são forças que se debatem nela na conclusão do período, se não nesse tempo todo. A vida de relação social implicada na função diplomática do marido constituía-se em lenta e prolongada tortura, que a esmagava e a derrubava numa sensação de apatia, de descolamento de si e de perda de contato com a própria potência ('espero um dia poder ser deste círculo vicioso em que minha alma caiu', diz ela em carta a uma de suas irmãs) ${ }^{7}$. 
6 Diante desse contexto, em que interioridade e exterioridade entram em tensão máxima, o autor comenta o que se gesta em Laços de família e será "implodido" (ou explodido) nos livros seguintes, que "testemunham um significativo deslocamento nos valores de classe média a partir dos anos 60" incluindo, sem dúvida, o estatuto do divórcio, até então inexistente:

Se os contos de Laços de família obedecem a um princípio concêntrico, nucleados por figuras que giram recorrentemente em torno do compromisso conjugal, os contos de A legião estrangeira retomam os mesmos elementos em movimento centrífugo. Atirados em estilhaços díspares para o mundo da estranheza e da falta, ao qual se abrem e no qual se movem. A Paixão segundo G.H., por sua vez, precipitará tudo isso no sorvedouro de uma nudez existencial sem precedentes, embora anunciada e já pulsante nos livros anteriores ${ }^{8}$.

7 Expostos os pilares da análise, entremos no texto Amor" transitando entre a crítica literária e a psicanálise, com primazia inconteste ao texto clariceano. Adianto que me intriga no conto o fato de que esses deslocamentos, referidos acima, se dão não só no plano geográfico (ou geopolítico), mas entre o mundo interno e externo, fazendo a personagem "viajar" em torno de si mesma, revisitando o passado e adentrando espaços subjetivos esquecidos ou deixados em estado de latência.

8 Tudo tem início numa travessia rotineira da protagonista, que volta com as compras do mercado no bonde. Refletindo, nos primeiros parágrafos, sobre a normalidade de sua vida de mãe e esposa, Ana parece se convencer (mas não ao leitor) de que "estava bom assim. Assim ela o quisera e escolhera" (p.31). Os filhos eram "coisa sumarenta e verdadeira" vocábulos que conflitam com o "sorriso de meia satisfação" com que Ana descansa no bonde. O casamento e a maternidade, ambos desejados, não parecem, contudo, satisfazê-la inteiramente. Ao lado de uma legião de mulheres da obra clariciana, divididas entre as lides diárias, com seu papel instituído e enrijecido, e uma "íntima desordem" contida e submersa prestes a emergir, Ana é trazida ao leitor pela técnica do fluxo de consciência com a qual o narrador mergulha em suas íntimas associações. Mescladas as vozes, seguimos a dona de casa enquanto declina as atividades em seu espaço doméstico, atribuindo-se a virtude de construir com as próprias mãos uma potente "corrente de vida". A ambiguidade do léxico conota tanto as algemas que aprisionam Ana aos elos e laços da rotina como o automatismo da corrente progressiva.

9 Ao longo do conto, veremos Ana deslocar-se - no duplo sentido da viagem a caminho de casa e da sucessão dos pensamentos -, passando da acomodação estável que a vida familiar lhe trouxera àquela "exaltação perturbada que tantas vezes se confundira com "felicidade insuportável"(p. 18, itálico meu). A expressão antitética refere-se ao tempo de sua juventude, vivida hoje como "uma doença de vida". o vago desejo artístico de então resolvera-se em gosto pelo decorativo" selando uma formação de compromisso" entre a vocação e a conformação. O esforço da personagem é represar e abafar a "hora perigosa da tarde", aquela que acomete a esposa-mãe, trabalhadora da casa, em seu vazio incômodo no momento em que cessam os "calmos deveres", esses que a aureolavam (a palavra é textual e santifica a atividade doméstica, grifo meu). Em suma, de um lado Ana é sólida e firme, enraizada no solo do lar, nutrindo a "aparência harmoniosa" das coisas. De outro, assombra-lhe a ameaça da inquietação, do desregramento, do descontrole e do contato com o que ficou para trás ao construir "uma vida de adulto". A quebra da barreira e o retorno indesejado da face recalcada rondam a narrativa. As 
mãos heroicas podem não conter mais os antigos desejos de expansão e a tão temida "íntima desordem".

\section{No meio do caminho tinha um cego}

10 É justamente a irrupção desse fundo silenciado, avesso a qualquer ordenamento, que surpreenderá Ana durante o prosaico percurso do bonde. Alguns índices prenunciam a intensidade e a violência do que está por vir: "o fogão enguiçado dava estouros" e a tesoura dava "estalidos na fazenda". O caráter explosivo ainda está contido, mas os fechos dos parágrafos que reagem às associações livres vão aos poucos cedendo ao material reprimido. Até o bonde se animiza, vacilando nos trilhos, prestes a perder sua rota. A hora instável de Ana se aproxima. Mais uma vez se reedita, nos textos de Lispector, a entrada abrupta de eventos disruptores, fazendo ruir uma aparente tranquilidade. Afinal, a periclitância das personagens claricianas, que nas palavras do texto "se mantinham por um mínimo equilíbrio à tona da escuridão", é uma marca inequívoca de sua literatura. Joana, Virgínia, Lucrécia, Macabéa ${ }^{9}$ - só para mencionar os romances - vivem exílios constantes, movimentações conflituosas entre o eu e o mundo. Talvez esteja aí uma transmutação complexa da própria trajetória biográfica de Lispector, sempre atravessada por desafios de adaptação e desenraizamentos vividos com sofrimento pela autora. Há uma noção de perigo iminente que permeia a obra como um rio subterrâneo, possível traço de desterros longínquos ${ }^{10}$.

11 No conto "Amor", o mediador dessas transições inesperadas é a aparição de um cego mascando chicle no ponto do bonde. 0 efeito dessa visão de alguém "que não nos vê" é fulminante e arrebatadora. Tudo o que há pouco era familiar e conhecido dissolve-se numa sinistra perda de referências. "O mal estava feito", diz a narração. Ana sente-se "expulsa de seus próprios dias" e a estranheza consigo mesma e com o ambiente que a cerca se mostra incontornável.

12 Ao primeiro tempo narrativo, empenhado em construir e desmontar gradualmente o falso edifício de solidez de Ana, seguem-se agora imagens deflagradas pelo efeito dos olhos abertos do cego, cuja alusão à vidência de Tirésias - que vê na escuridão - revela a cegueira de Ana em relação à sua própria história. As metáforas aludem à emergência do que sempre esteve aquém do esforço civilizacional: "[...]o pesado saco de tricô despencou-se, ruiu no chão [...] os ovos se haviam quebrado no embrulho do jornal. Gemas amarelas e viscosas pingavam entre os fios da rede" (p. 19). O que até então se manteve preso, contido pelos laços socioculturais e familiares, rompe sua tênue proteção - casca/rede, frágil camada egóica - e o interior escorre como matéria primal rediviva. Esse mundo viscoso, informe, volátil é da mesma natureza de outras figurações que se espalham pela obra de Lispector: a placenta que se movimenta de forma assustadora em "A geleia viva como placenta"(A legião estrangeira), massa disforme e matriz do corpo humano a ser constituído; ou ainda a pigmeia grávida descoberta no fundo da floresta equatorial do conto "A menor mulher do mundo" (Laços de familia), protótipo ancestral e rudimentar da espécie humana, confrontada com a suposta superioridade do explorador francês e "dono do mundo" Marcel Pretre.

13 Todas essas imagéticas insólitas configuram um campo imantado por um mesmo malestar que acompanha personagens (e leitores) em seus périplos. $O$ bonde, que antes se arrastava e estacava, passa a sacudir-se nos trilhos, em flagrante homologia ao estado da personagem. 0 que se esconde neste mal-estar? Talvez se possa aproximá-lo ao 
complexo "Das Unheimliche" freudiano, ou seja, ao retorno angustiante do que deveria ficar escondido e vem à luz ${ }^{11}$. A sensação de pertencimento a um lugar confiável, a um abrigo seguro e cômodo, moldado nos primeiros parágrafos do conto, se esvai com o derramamento das gemas por entre os fios da rede. O que antes era "heim (lar, morada), que podemos estender para "heimat" (que em alemão tem o sentido de "terra natal", pátria mãe, lugar de origem) se torna adverso, irreconhecível:

A rede de tricô era áspera entre os dedos, não íntima como quando a tricotara. A rede perdera o sentido e estar num bonde era um fio partido; não sabia o que fazer com as compras no colo. E como uma estranha música, o mundo recomeçava ao redor. 0 mal estava feito (p. 33).

14 Nas frestas do mais prosaico cotidiano emerge o sentimento de estrangeiridade que comentei acima, sendo o estrangeiro esse outro de nós com o qual dividimos nosso eu (suposto como único, íntegro e absoluto) e do qual nos alijamos. $O$ que foi clivado pelas forças defensivas do sujeito se vê impelido a retornar. Espanto, perplexidade, excesso de uma pulsionalidade sem contorno invadem Ana sob a forma sem forma da experiência de "Das Unheimliche". Justamente por estar tão dentro dela, seu mais próximo desconhecido, esse núcleo tão íntimo não incorporado ao eu, se exterioriza como estranha presença desorganizadora ${ }^{12}$. Mas a vivência, para expressar-se como incômodo estranhamento, necessita do contato, da ativação com um outro, que só se dá quanto dentro e fora, sujeito e mundo se tocam (ainda que à distância). Aquele que "mascava goma na escuridão" arrasta a boa esposa e mãe de família para fora de seu habitat (palavra relativa a "hábito"). 0 acontecimento do âmbito da esfera pública aciona a crise, tão pressentida e evitada, cuja marca "era o prazer intenso com que olhava agora as coisas, sofrendo espantada" (p. 33-34) ${ }^{13}$. Uma nova percepção se anuncia e Ana reconhece nas pessoas o que sua vida adornada e arrumada não podia até então permitir:

[...] por um momento, a falta de sentido deixava-as tão livres que elas não sabiam para onde ir. Perceber uma ausência de lei foi tão súbito que Ana se agarrou ao banco da frente, como se pudesse cair do bonde, como se as coisas pudessem ser revertidas com a mesma calma com que não o eram (p. 33).

"Falta de sentido", liberdade e "ausência de lei" são o avesso do que a consciência se permite e manifestam o perigo de uma intensa perdição. A extasiante liberdade traz a insígnia do assustador e a perigosa relativização de infinitas reversões.

Voltando à curiosa mastigação do cego, inevitável lembrarmos da crônica "Medo da eternidade" (6/6/1970), na qual Clarice narra sua primeira experiência, quando criança, com um chicle dado pela irmã. Diz ela: "Jamais esquecerei o meu aflitivo e dramático contato com a eternidade"14. A irmã oferece a bala "que nunca se acaba" e "dura a vida inteira". Ao provar "o elixir do longo prazer", Clarice criança toma todo cuidado para não "perder a eternidade". Mas passado o sabor, "em breve tinha na boca o puxa-puxa cinzento de borracha que não tinha gosto de nada [...] E a vantagem de ser bala eterna me enchia de uma espécie de medo, como se tem diante da ideia de eternidade ou de infinito" (p. 290). Quando resolve "perder" de propósito a bala eterna deixando-a cair no chão, sente-se aliviada, como se lê ao final: "Sem o peso da eternidade sobre mim" (p. 291).

17 É possível que a substância amorfa do chicle seja mais uma condensação da tal "coisa" clariciana, ao lado das gemas pingando, da geleia placentária se arrastando sobre a mesa, da pigmeia pré-linguística, da galinha desajeitada e visceral (do conto "Uma galinha") ${ }^{15}$. Na chave simbólica aqui proposta, a angústia da eternidade, presente na 
mastigação do chicle (e na alternância entre "sorrir e deixar de sorrir" do cego, engendrando mutações infinitas da forma), parece corresponder à ausência de lei e de contorno que aterroriza a personagem do conto. É dessa ordem também o horror que a massa branca indelimitada da barata provoca em G.H. no romance A paixão segundo G.H, de 1964.

\section{Paradas}

Observando mais de perto a descrição da cena em que o cego faz desmoronar o sistema codificado de Ana, veremos dois polos que se alternam na camada semântica do texto: o movimento e a parada. $O$ primeiro parece se referir a uma espécie de moto contínuo automático, robotizado - a tal "corrente de vida" - que mantém Ana em um fluxo anestesiado, até que um cego a desperte. A vida administrada em sua continuidade e persistência é desafiada perigosamente pelo "homem parado no ponto". A narração insiste: "A diferença entre ele e os outros é que ele estava realmente parado" (p. 32, grifo meu).

Desde o início, há uma ênfase nos signos de parada: "Mas o vento batendo nas cortinas que ela mesma cortara lembrava-lhe que se quisesse podia parar e enxugar a testa, olhando o calmo horizonte" (p. 29. grifo meu). Ou então: a freada brusca do bonde (que depois se arrastava e estacava), a imobilidade de Ana para apanhar as compras caídas no chão, a sua atitude inerte olhando o muro do Jardim Botânico, o silêncio estático (e extático) do Jardim e do gato. É preciso que algo deixe de se movimentar para que outro modo de existência venha à tona. Quando Ana salta do bonde como "no meio da noite" e atravessa às cegas os portões do Jardim Botânico, um novo e pulsante mundo vivo se apresenta aos seus sentidos. "Tudo era estranho demais, suave demais, grande demais". A experiência do excesso que a personagem vislumbra no "trabalho secreto" do Jardim é o que ela desconhece em si mesma: ruídos, cheiros, tatos, erotismo de uma natureza (sua e do Jardim) "faiscante" e "sombria", que a levam a perverter o sentido até então instituído: "A moral do Jardim era outra". Também Ana era outra, vivendo agora aquela estrangeira que nela habitava como uma "doença de vida".

A dimensão pulsativa do Jardim parece fundir-se à personagem, contagiá-la com sua intensidade. Ana experimenta a sensação de algo vasto e indefinido, uma conexão nova entre ela e o mundo. As plantas surgem em sua carnalidade e se mesclam à sensorialidade e ao psiquismo da personagem: "Ao mesmo tempo que imaginário - era um mundo de se comer com os dentes, um mundo de volumosas dálias e tulipas. 0 abraço era macio, colado. Como a repulsa que precedesse uma entrega - era fascinante, a mulher tinha nojo, e era fascinante" (p. 36).

Sobre essa vivência singular, que a crítica nomeou de epifania a partir dos estudos de Benedito Nunes, retomados por Olga de Sá e Affonso Romano de Sant'anna, o crítico João Camillo Penna prefere considerar sob outro viés. Essa percepção alterada, que se revela na obra de Clarice, desde seu primeiro livro Perto do coração selvagem (1943), pediria, na visão do crítico, uma revisão do conceito de "epifania". Para Camillo Penna, o que Ana e tantas outras personagens vivenciam em estado de perplexo espanto, misto de estranhamento e descoberta, náusea e encanto, remeteria à uma ideia de "revelação da unicidade das coisas" ao invés da aparição de uma essência divina na matéria (marca de uma ascendência religiosa, como está na origem do vocábulo ephifaneia). Partindo da frase de Joana, protagonista do romance inaugural, que afirma que "Tudo é um", Penna 
entende que "não se trata mais de colher a beleza do mundo em sua encarnação material, mas de perscrutar a rede imaterial na qual a matéria das coisas se dissolve e se resolve" ${ }^{\prime \prime}$.

Ainda dentro desta perspectiva, o que Ana vivencia no Jardim é o espaço interconectado entre sujeito e coisas, seres e mundo, eliminando assim as divisas que separam os entes e obscurecem o fio que os tece neste "Tudo é um". Vale a pena citar o crítico:

A revelação da verdade do mundo se encontra na rede de ligações que entrelaçam as coisas num conjunto único, o ponto enigmático de sua 'confusão'. A fórmula ontológica enunciada com simplicidade e rigor pela autora aos vinte anos, consiste no sentimento de que as coisas remetem a algo que não é propriamente elas, mas à ligação, ao enlaçamento que as liga[...] $]^{17}$.

O ensaísta apropria-se do título de uma crônica de Clarice, "Estado de graça - Trecho", de 6 de abril de 1968, analisado por ele, para denominar essa particular experiência. Esse "estado de graça"18 não se confunde com inspiração artística ou com a graça mística dos santos. Trata-se, nas palavras da escritora, da "dádiva indubitável de existir materialmente" 19 . Ainda que extasiante, há perigo nesta imersão na insuportável felicidade, o que nos leva de volta ao conto "Amor".

24 Antes mesmo do transe no Jardim começar, o narrador faz a suma do processo até então: "Ela apaziguara tão bem a vida, cuidara tanto para que esta não explodisse [...] E um cego mascando goma despedaçava tudo isso" (p. 34). Seria essa a voz da consciência de Ana diante da crise ou a voz narrativa que vê mais longe que a personagem? A "bondade extremamente dolorosa" na qual caíra Ana, ao lado da "náusea doce" que a acomete, são expressões que estendem o estranhamento para a própria linguagem. "O Jardim era tão bonito que ela teve medo do inferno". "Era fascinante, e ela sentia nojo", ou ainda a expressão "suavidade intensa".

Os termos se contradizem criando terceiras margens da língua, lugar estranhado que expande o campo de paradoxos, antíteses e oxímoros e dá corpo à insólita experiência. o desvio da linguagem comum é o cerne de toda literatura, mas aqui o gesto se potencializa porque mimetiza a metamorfose da própria protagonista. Seria afim ao que Platão afirma sobre o discurso poético: "O ser se enlaç (a) ao não ser, de maneira a mais estranha" ${ }^{20}$. A esse respeito, cito José Paulo Paes quando comenta duas noções básicas para a descrição do funcionamento da metáfora n'Arte Retórica, de Aristóteles:

Em primeiro lugar, a noção de desvio do 'sentido ordinário' das palavras como meio de dar elevação ao discurso; em segundo lugar, a noção da admirativa estranheza que tais desvios suscitam: [citando Aristóteles] 'Importa dar ao estilo um ar estrangeiro, uma vez que os homens admiram o que vem de longe e que a admiração gera

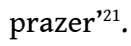

E mais adiante, Paes insiste: “Aristóteles distingue as metáforas como 'o meio que mais contribui para dar ao pensamento [...] o ar estrangeiro de que falamos' e delas diz outrossim que "são enigmas velados" 22 . Trata-se, portanto, de imagens estrangeiras ao léxico conhecido, resultantes de procedimentos específicos, como por exemplo sobrepor substantivo ao adjetivo não conatural (os exemplos são inúmeros na obra toda: "horrível mal-estar feliz", "alegria difícil", entre outros), ao lado de hipérboles que no conto agigantam cenas prosaicas como essa: "Um cego mascando chicle mergulhara o mundo em escura sofreguidão" (grifo meu). Atrelam-se, assim, forma e conteúdo de um modo inextricável, condensando o excesso de desorientação de Ana. 


\section{A volta} quanto mais ela busca adequar-se aos padrões de gênero feminino na estrutura familiar patriarcal. O que Laura, a protagonista, internalizou como "normal" é exatamente o lugar no qual vai se perder. Sua loucura, após a visão de uma simples e bela rosa no vaso (e a flor tem uma função similar à do cego em "Amor") faz eclodir o desejo aprisionado pela obsessão adaptativa. Já no caso de Ana, "a vida sadia que levara" antes do trânsito pelo Jardim ressurge em todo seu estranhamento tornando-se uma vida louca, enquanto o seu arrebatamento no Jardim se revela a via moralmente saudável. A peripécia parece colocar em xeque identidades fixadas por padrões inquestionáveis, desequilibrando um sistema de crenças e valores mantido com muito custo. em mais uma imagem transgressora do senso comum. O filho será visto como um desconhecido, fora da rede familiar, "um ser de pernas compridas e rosto igual ao seu" (p. 37), ao qual pede que não a deixe esquecê-lo. Após ter tocado na tessitura de viver, haveria volta ao lugar da ordem social? "Não havia como fugir. Os dias que ela forjara haviam se rompido na crosta e a água escapava. Estava diante da ostra. E não havia como não olhá-la" (p. 39). A paranomásia crosta/ostra retoma a imagem inicial da casca/ gema. Algo vaza do interior rompendo a barreira (do recalque?). 0 efeito subjetivo da quebra do dique encontra na palavra "horror", repetida várias vezes ${ }^{23}$, sua expressão maior. A inquietante estranheza, no entanto, caminha ao lado de sensações positivas ou que retomam as descobertas e insights vividos antes. Ana reencontra o "trabalho secreto" do Jardim ali dentro de seu espaço doméstico: "O pequeno horror da poeira ligando em fios a parte inferior do fogão, onde descobriu a pequena aranha" (p. 39). Até mesmo a imanência do ato de parar, já analisada, ressurge com as gotas d'água que "caíam na água parada do tanque"(grifo meu). Pontes entre o exterior e o interior (do jardim, da casa e de si), antes imperceptíveis, tornam-se nítidas.

31 A vivência "Das Unheimliche", que Freud desentranha da literatura fantástica de E.T. Hoffmann, fundada na emergência de sentimentos e efeitos assustadores e 
angustiantes, ganha na literatura clariceana uma face luminosa que tensiona o desassossego. O estranhamento também é impulso para renovação, conjugando angústia e revelação.

Chamo, ainda, atenção às imagens circulares, seja de gestos, situações, bichos ou objetos situados no espaço, que rondam a personagem, sobretudo após o passeio pelo Jardim. Alguns exemplos: "Ao redor havia uma vida silenciosa e lenta, insistente" (p. 39). [...] Andava de um lado para outro na cozinha, cortando os bifes, mexendo o creme. Em torno da cabeça, em ronda, em torno da luz, os mosquitos de uma noite cálida" (p. 40). E depois, na cena do jantar em família, banhado de um amor novo, nascido da fusão de opostos, em que todos estão "felizes em não discordar, tão dispostos a não ver defeitos", a frase "Eles rodeavam a mesa, a família"(grifos meus) consagra a circularidade como figura central. Penso que sua significação é ainda mais expressiva em contraste com uma certa geometria da linearidade progressiva da primeira parte do conto, feita de linhas que se enraízam ou caminham para diante, pouco afeitas às esferas advindas da aventura transformadora de Ana. Alguns exemplos: os filhos, as árvores e a mesa com comidas "cresciam", verbo de positividade quase bíblica ${ }^{24}$. Para se defender de sua fragilidade, que começa a revelar-se ao leitor (em uma segunda voz que faz vir à tona o que antes lhe era inconsciente), a personagem "sentia-se mais sólida do que nunca" e "sempre tivera necessidade de sentir a raiz firme das coisas". Solidez e enraizamento se opõem aos movimentos concêntricos após a travessia do amor no Jardim Botânico. Ou seja, há uma mudança imagética no conto que faz o movimento automático da primeira parte, dirigido pela "corrente de vida", transmutar-se em imagens mandálicas, onde tudo rodeia tudo e o mundo, a natureza, as pessoas fazem parte do tecido da vida ${ }^{25}$. A heroína do lar mergulha agora na vida rodeante, estranhando a horizontalidade e verticalidade anteriores. Vertigem e ondas no lugar de vetores metódicos ${ }^{26}$.

\section{Epílogo}

Quando o jantar termina, acercamo-nos do final do conto. Ainda tocada pelo chamado extasiante do Jardim e com a percepção cotidiana alterada, Ana se assusta com o barulho do estouro do fogão, já mencionado nos primeiros parágrafos. Agora o ruído parece corroborar um outro estouro: "Hoje de tarde alguma coisa intranquila se rebentara[...]" (p. 41), afirma o narrador. Ao olhar a esposa e seu "estranho rosto", o marido "cansado, com olheiras"(também o homem do lar parece exausto em seu lugar de provedor), "segurou a mão da mulher, levando-a consigo sem olhar para trás, afastando-a do perigo de viver" (p. 41). Cumprindo um papel avesso ao do cego (que arrasta Ana ao coração selvagem da vida), a personagem masculina retira Ana do mergulho na escuridão e protege, assim, os frágeis e firmes laços de família.

A esse respeito, vale lembrar também o conto "Os laços de família", que dá título ao volume. Nele, a posição do marido se vê ameaçada com a volta da esposa após um encontro intenso entre ela e a mãe (efeito de um esbarrão entre ambas no taxi). Ele a vê da janela caminhar com o filho e pressente um abismo entre ele e os dois que se compreendem "dentro do mistério partilhado". "Mas e eu? E eu? Perguntou assustado. Os dois tinham ido embora sozinhos. E ele ficara" (p. 126). Neste caso, o lugar paterno é francamente destoante da posição materna, vista com desconfiança em sua transmissão geracional, enquanto em "Amor" a atmosfera que envolve o casal é de maior 
cumplicidade, ainda que Ana também tenha se desgarrado por alguns momentos da cadeia familiar. Ironicamente, a mulher neste volume de contos, constrangida por elos conformadores socioculturais, ganha imprevista potência diante do lugar dominante masculino justamente ao viver a força do estranhamento... O portal ritualístico pelo qual as mulheres claricianas atravessam - distraídas ou desprevenidas -, raramente se apresenta aos homens. E o que as mulheres vislumbram nessas travessias, sem qualquer planejamento ou intenção, basta para que as peças se movam, definindo novas posições ou reflexões para ambos os sexos.

o último parágrafo traz a ambiguidade da cena para o leitor decidir ele mesmo o impasse em aberto: " $E$ se atravessara o amor e o seu inferno, penteava-se agora diante do espelho, por um instante sem nenhum mundo no coração. Antes de se deitar, como se apagasse uma vela, soprou a pequena flama do dia" (p. 41). Estranhar pode ser, ainda que "por um instante", passagem pelo vazio (sem mundo no coração) e pelo escuro do quarto apagado. A flama do dia talvez venha a ser acesa em outro momento, garantida a aprendizagem de um olhar estrangeiro para o mundo. Ou será que o sopro da vela levou junto a fugaz renovação trazida pela insólita estranheza? A imagem dupla tensiona os sentidos e impede o absoluto de uma conclusão.

De fato, o conto todo desloca o próprio leitor e sua expectativa de um desfecho apaziguador. As significações comuns são transgredidas, relativizadas ou colocadas em suspenso. Pelas reversões do conto, o "progresso" aparente inicial de Ana e seu automatismo na "corrente de vida" são vistos como paralisia; já a estaticidade do cego, a quietude, a contemplação e as paradas adquirem valor positivo por proporcionar a escuta de uma outra dinâmica vital: o rumorejar das águas, o abraço macio das plantas folhudas no tronco das árvores, a visão da família reunida... 0 que está parado se mostra repleto de vivacidade. 0 que se mexe, como a vida mecanizada de Ana, pode ser uma grande estagnação.

Agora retomo os fios lançados no início deste ensaio. 0 campo da estrangeiridade ao qual Ana se expôs a partir da visão do cego e que foi aqui aproximado ao "Das Unheimliche" de Freud, implica a suspensão do sentido habitual dos objetos e seres antes familiares ${ }^{27}$. A sensação que acompanha este estado é a perda do sentimento de pertencimento, o que nos leva a considerar o constante exílio das personagens claricianas. Talvez se insinuem aqui as tais marcas judaicas que se deixam entrever, em surdina, nesse jogo entre parar e se mover. É possivel que os emigrantes de todos os tempos, aos quais Clarice se alia e com os quais partilha legados intangíveis, tenham forjado, em meio a uma movimentação sem fim, um modo de proteger (ou reconhecer) a vida em cada pedaço do instante, em cada trégua de tantas novas paradas. Para tanto, foi preciso atravessar, como Ana, "o amor e o seu inferno", padecendo a dor e o êxtase das grandes viagens. Em "Amor", Lispector narra um percurso da rua para a casa (pelo bonde), desviando-se para o jardim Botânico e deste retomando o caminho de casa, levando Ana de volta ao lar. o êxodo se fecha com o retorno ao que é próprio e íntimo, mas não sem uma indagação crucial: "O que o cego desencadeara caberia nos seus dias?" (p. 40).

Penso ser peculiar à condição humana despertar de tempos em tempos para o "perigo de viver". Mas talvez seja demasiado manter-se de pé, parado, entregue a tanta vida. 


\section{BIBLIOGRAFIA}

Nádia BATElla Gotlib, « Os difíceis laços de família », Cadernos de Pesquisa Fundação Carlos Chagas, n 91 (nov. 1994), p. 93-99.

Sigmund FREUD, « O infamiliar » [Das Unheimliche], édition bilingue, trad. Ernani Chaves et Pedro Heliodoro Tavares, Obras Incompletas de Freud, vol. 8, Belo Horizonte, Autêntica, 2019.

Caterina KOLTAI, Política e psicanálise. O estrangeiro, São Paulo, Escuta, 2000.

Clarice LISPECTOR, Laços de família, Rio de Janeiro, Francisco Alves, 1991.

Clarice LISPECTOR, A descoberta do mundo, Rio de Janeiro, Rocco, 1999.

Clarice LISPECTOR, « Estado de graça », A descoberta do mundo, Rio de Janeiro, Rocco, 1999.

José Paulo PAES, « Por uma pedagogia da metáfora », Vilma Arêas (org.), Armazém literário, São Paulo, Companhia das Letras, 2008.

João Camillo PENNA, « O nu de Clarice », Alea: Estudos Neolatinos, vol. 12, n 1 (junho 2010), s/p.

Regina Lúcia PONTIERI, « Peru versus galinha. Aspectos femininos em Mário de Andrade e Clarice Lispector ", Revista Literatura e Sociedade, vol. 3, nº 3 (1998), p. 43-50.

Regina Lúcia PONTIERI, «Visões da alteridade: Clarice Lispector e Maurice Merleau-Ponty », Revista USP, nº 44 (déc-jan-fev 1999-2000), p. 330-334.

Anatol RoSENFELD, « Reflexões sobre o romance moderno », Texto/Contexto, São Paulo, Perspectiva, 1975.

Berta WALDMAN, Entre passos e rastros. Presença judaica na literatura brasileira contemporânea, São Paulo, Perspectiva/Fapesp/Associação Universitária de Cultura Judaica, 2003.

José Miguel WISNIK, « Diagramas para uma trilogia de Clarice », LETRAS, Curitiba, n 98 (jul/ déc 2018).

\section{NOTAS}

1. Clarice LISPECTOR, Laços de família, Rio de Janeiro, Francisco Alves, 1991, p. 32. A partir de agora as páginas desta edição serão citadas diretamente no corpo do texto.

2. Para mais detalhes, consultar Nádia BATELla Gotlib, Uma vida que se conta, São Paulo, Edusp, 2013 ; Teresa MONTERO, Eu sou uma pergunta, Uma biografia sobre Clarice Lispector, Rio de Janeiro, Rocco, 1999 ; Benjamin MOSER, Clarice, Companhia das Letras, São Paulo, 2017.

3. Berta WALDMAN, Entre passos e rastros. Presença judaica na literatura brasileira contemporânea, São Paulo, Perspectiva/ Fapesp/Associação Universitária de Cultura Judaica, 2003.

4. Olga BORELLI, Clarice Lispector: esboço para um possível retrato, Rio de Janeiro, Nova Fronteira, 1981, p. 111.

5. Berta WALDMAN, op. cit., p. 18.

6. Para a psicanalista Caterina Koltai, a figura do estrangeiro se "situa na fronteira do subjetivo singular com o social". Derivado do latim, o adjetivo extraneus significava, até o século XIV, apenas alguém "vindo de fora". A politização do termo se dá a partir do século XV, fazendo o nãofamiliar se tornar um conceito com implicações políticas: “[...] A categoria sociopolítica que o 
estrangeiro ocupa o fixa numa alteridade que implica, necessariamente, uma exclusão". Caterina KOLTAI, Política e psicanálise. 0 estrangeiro, São Paulo, Escuta, 2000, p. 21-22.

7. José Miguel WISNIK, "Diagramas para uma trilogia de Clarice”, LETRAS, Curitiba, n 98 (jul/déc 2018), p. 284.

8. Ibid., p. 285.

9. Protagonistas, respectivamente, de Perto do coração selvagem (1943), O lustre (1946), Cidade sitiada (1949), A hora da estrela (1977). Volto à ideia mais adiante.

10. Ressaltem-se aqui, como pano de fundo crucial para o entendimento da literatura moderna, as grandes rupturas advindas com as vanguardas, que atingem o cerne das categorias romanescas tradicionais. O efeito de descentramento das personagens, do tempo, do espaço e do enredo responde à crise da representação em meio ao mundo destruído pelas guerras. Ver Anatol ROSENFELD, "Reflexões sobre o romance moderno", Texto/Contexto, São Paulo, Perspectiva, 1975, p. 75-91.

11. Como se sabe, no famoso ensaio de 1919, "Das Unheimliche”, cuja tradução para a palavra "Infamiliar" será adotada a partir de agora, Freud empreende uma longa pesquisa lexicológica, filosófica e literária para reconhecer que o termo, no limite intraduzível, abriga no mesmo vocábulo afirmação e negação do que é conhecido, familiar e doméstico. 0 "un" é a partícula de negação acrescida à palavra "heimlich" que, por sua vez, também apresenta ambiguidade. Tratase de algo positivo e negativo simultaneamente, já que o que é íntimo/sabido/familiar também pode ser oculto e secreto. "Das Unheimliche" ressoa, portanto, uma dupla negação, na qual a ambivalência semântica manifesta a presença do recalque (prefixo "un"). A coincidência dos opostos na mesma palavra, o que torna o familiar infamiliar, é aproveitada por Freud quando cita Schelling: "Infamiliar seria tudo o que deveria permanecer em segredo, oculto, mas que veio à tona". Em "O infamiliar". [Das Unheimliche]. Edição bilíngue. (Seguido de "O homem da areia", de E.T. Hoffmann). Trad. Ernani Chaves e Pedro Heliodoro Tavares (Freud) e Romero Freitas (Hoffmann), Obras Incompletas de Freud, vol. 8, Belo Horizonte, Autêntica, 2019, p. 45.

12. Vale mencionar que Lacan criou um neologismo que abarcaria o fenômeno identificado ao "Das Unheimliche" de Freud, em 1960 no Seminário 7: A Ética da Psicanálise. Trata-se do termo "extimidade" ("extimité", em francês, "extimus" no latim) que se opõe à intimidade assim como o vocábulo "exterior" se opõe a "interior". Lacan cria o termo para designar algo que é íntimo ao sujeito, mas encontra-se em seu exterior. Existiria um lugar central ao sujeito do qual, no entanto, ele está distante. De fato, para o psicanalista, o Outro será o êxtimo do sujeito, já que todos nós existimos primeiro fora, no discurso do Outro.

13. No ensaio "Os difíceis laços de família", Nádia Batella Gotlib considera que Ana "mergulha na identidade dos não limites, que se caracteriza pela disponibilidade diante do 'vir a ser', tal como a propõe Gilles Deleuze [...]em que há o deslizamento do sentido, em direção ao tudo que é possível". De fato, o caminho de Ana fará convergir os opostos, eliminando as fronteiras entre eles. Nádia BATELla Gotlib, "Os difíceis laços de família", Cadernos de Pesquisa Fundação Carlos Chagas, n91 (nov. 1994), p. 96.

14. Clarice LISPECTOR, A descoberta do mundo, Rio de Janeiro, Rocco, 1999, p. 289.

15. Sobre a questão da alteridade em Clarice Lispector, ver Regina PONTIERI, "Peru versus galinha. Aspectos femininos em Mário de Andrade e Clarice Lispector", Revista Literatura e Sociedade, vol. 3, n³, 1998, p. 43-50 e Regina PONTIERI, "Visões da alteridade: Clarice Lispector e Maurice MerleauPonty”, Revista USP, nº4 (dez-jan-fev 1999-2000, p. 330-334. Também remeto o leitor ao livro de Daniela Kahn sobre o tema: A via crucis do outro, São Paulo, Humanitas, 2005.

16. João Camillo PENNA, “O nu de Clarice”, Alea: Estudos Neolatinos, vol. 12, n¹ (juin 2010), s/p.

17. Ibid., s/p.

18. Clarice LISPECTOR, "Estado de graça", A descoberta do mundo, Rio de Janeiro, Rocco, 1999, p. 91-93. 
19. Ibid., p. 91.

20. Apud José Paulo PAES, "Por uma pedagogia da metáfora", Vilma Arêas (org.), Armazém literário, São Paulo, Companhia das Letras, 2008, p. 109.

21. Ibid., p. 109.

22. Ibid.

23. Entre eles "Carregando a jarra para mudar a água - havia o horror da flor se entregando lânguida e asquerosa às suas mãos" (p.39). Ou mais adiante: "O horror dos besouros inexpressivos" (p. 39).

24. Nádia BATELLA GOTLIB, op. cit.

25. Assim como Camillo Penna observou a interconexão das coisas na ideia de "estado de graça", Pontieri recorre a Merleau-Ponty para abordar essa ideia de um mundo-carne que envolve a relação entre sujeitos. Ver "Visões da alteridade: Clarice Lispector e Maurice Merleau-Ponty", op. cit.

26. O conto "Devaneio e embriaguez de uma rapariga", anterior a "Amor", parece antecipar (na forma cômica do estilo que imita a dicção lusitana), esse tópico da circularidade. A personagem amanhece com ressaca, largada na cama a devanear, com graça e sentindo os excessos de álcool e de fantasias após um jantar na noite anterior com o marido e seu amigo. A mesma sensação de desfazimento dos elos domésticos leva a protagonista a uma entrega corporal similar a de Ana: "E, como entrefechara os olhos toldados, tudo ficou de carne, o pé da cama de carne, a janela de carne, na cadeira o fato de carne que o marido jogara, e tudo quase doía. E ela cada vez maior, vacilante, túmida, gigantesca. Se conseguisse chegar mais perto de si mesma, ver-se-ia inda maior. Cada braço seu poderia ser percorrido por uma pessoa, na ignorância de que se tratava de um braço, e em cada olho podia-se-lhe mergulhar dentro e nadar sem saber que era um olho. E, ao redor tudo a doer um pouco. As coisas feitas de carne com nevralgia. Fora o friozito que a tomara ao sair de casa de pasto". Clarice LISPECTOR, op cit., 2006, p. 14-15 (grifo meu). Ressurge aqui a dimensão "carne do mundo", comentado na nota anterior.

27. Nisso reside a afinidade entre dois ensaios que trabalham com a noção de estranhamento, escritos praticamente na mesma época: o de Freud, já referido, e o de Victor Chklovski, de 1917, "A arte como procedimento". Para o pensador russo, que integrava o vanguardista Círculo do Formalismo Russo, estranhamento ou desfamiliarização é um efeito que se produz por procedimentos estéticos que visam singularizar e descontextualizar objetos conhecidos e habituais. Segundo Chklovski, a percepção desautomatizada é o fundamento da arte, que a constrói em rigoroso processo de vigília. Para Freud, "Das Unheimliche" é uma qualidade da sensação e do sentir, portanto submetida à lógica dos afetos e implica em recalques inconscientes. Victor CHKLOVSKI, “A arte como procedimento”, Dionísio DE TOLEDO (org.), Teoria da literatura: Formalistas russos, Porto Alegre, Globo, 1973.

\section{RESUMOS}

Le but de cet essai est d'analyser en profondeur le conte "Amor », de Clarice Lispector, inséré dans le volume Laços de família (1960). L'opérateur de lecture sera l'étude de Freud «Das Unheimliche ", de 1919, qui se concentre sur l'effet d'étrangeté comme retour d'expériences refoulées, générant angoisse et étonnement. A côté de cette notion psychanalytique, la lecture cherchera à suivre, en lecture attentive, les modes de construction du récit, en privilégiant les 
procédures du langage, qui est aussi rendu étrange grâce à des choix lexicaux et syntaxiques singuliers. Enfin, le parcours de l'héroïne sera abordé dans son passage de l'ordre domestique à l'ordre du non-familier, qui remet en cause une forme de vie déjà consolidée.

The objective of this paper is to analyze in depth the short story "Amor", inserted in the work Laços de familia (1960), by Clarice Lispector. We will draw on Freud's 1919 essay "Das Unheimliche", which focuses on the uncanny as the return of the repressed experiences, which, in turn, generate anxiety and fright. In line with this psychoanalytical notion, this account will endeavor to follow, in close reading, the manners in which the narrative was constructed, favoring the processes of language, which is also perceived as eerie due to peculiar lexical and synthetic choices. Finally, the protagonist's trajectory will be studied in its passage from domestic to unfamiliar order, which jeopardizes a consolidated way of life.

\section{ÍNDICE}

Mots-clés: Clarice Lispector, étrangeté, psychanalyse, Laços de família, Amor Keywords: Clarice Lispector, uncanny, psychoanalysis, Laços de família, Amor

\section{AUTOR}

\section{YUDITH ROSENBAUM}

Universidade de São Paulo 